\title{
The use of supramolecular structures as protein ligands
}

\author{
Barbara Stopa • Anna Jagusiak • Leszek Konieczny • \\ Barbara Piekarska • Janina Rybarska • \\ Grzegorz Zemanek • Marcin Król • Piotr Piwowar • \\ Irena Roterman
}

Received: 21 October 2012 / Accepted: 17 December 2012 /Published online: 8 January 2013

(C) The Author(s) 2013. This article is published with open access at Springerlink.com

\begin{abstract}
Congo red dye as well as other eagerly selfassembling organic molecules which form rod-like or ribbonlike supramolecular structures in water solutions, appears to represent a new class of protein ligands with possible wideranging medical applications. Such molecules associate with proteins as integral clusters and preferentially penetrate into areas of low molecular stability. Abnormal, partly unfolded proteins are the main binding target for such ligands, while well packed molecules are generally inaccessible. Of particular interest is the observation that local susceptibility for binding supramolecular ligands may be promoted in some proteins as a consequence of function-derived structural changes, and that such complexation may alter the activity profile of target proteins. Examples are presented in this paper.
\end{abstract}

Keywords Congo red $\cdot$ Supramolecular ligand

\section{Introduction}

The search for new drugs and protein reagents usually involves single organic molecules which attach to protein

B. Stopa $\cdot$ A. Jagusiak $\cdot$ L. Konieczny $\cdot$ B. Piekarska $\cdot$

J. Rybarska $\cdot$ G. Zemanek

Medical Biochemistry, Jagiellonian University - Medical College,

Kopernika 7,

31-034 Kraków, Poland

\section{Król · I. Roterman $(\bowtie)$}

Department of Bioinformatics and Telemedicine, Jagiellonian

University - Medical College, Lazarza 16,

31-530 Kraków, Poland

e-mail: myroterm@cyf-kr.edu.pl

\section{P. Piwowar}

Department of Measurement and Instrumentation,

AGH - University of Science and Technology, Al. Mickiewicza 30,

31-059 Kraków, Poland binding sites. Such studies are widely supported by computer-aided drug design tools $[1,2]$, however ongoing developments in supramolecular chemistry have directed the attention of researchers toward new types of reagents, formed by assembling several distinct chemical compounds. These reagents are potentially attractive due to their unique properties and possible applications in various fields [3-13]. From the medical and biological point of view interaction of supramolecular structures with proteins is a topic of great interest, yet - unfortunately - our knowledge of this phenomenon remains limited. Interaction of this type is known to occur in cell membranes; however surface interaction with proteins (such as in the cell membrane) is not sufficient to facilitate biological function. Penetration of a ligand composed of assembled molecules into the protein interior seems necessary. Out of many possible supramolecular architectures rode-like or ribbon-like organization appears to be the most promising for this purpose due to the existence of partly exposed hydrophobic portions of assembled compounds, favoring adhesion. Congo red is perhaps the best recognized self-assembling dye of this type and hence commonly used as a model [14-17]. It is a known amyloid stain but it also appears to form complexes with structurally unstable proteins, such as abnormal IgG light chains derived from serum or urine of myeloma patients [18-23]. Molar excess of this dye usually attaches to proteins and while a large fraction of the bound dye may easily be removed by adsorption, some dye usually remains, suggesting penetration and anchorage within the protein body. A question therefore arises: should penetrating molecules be treated as assemblages of individual units or as an integral ligand? Support for the latter interpretation is provided by studies on some foreign compounds, e.g., rhodamine B intercalating into supramolecular Congo red and penetrating, together with this dye, into a protein for which it has no affinity by itself [24]. Moreover, the observed correlation of 
self-assembling tendencies of different organic dyes and their capability for protein complexation strongly favors treating supramolecular liagands as coherent units $[25,26]$. An integrated supramolecular ligand seems necessary to achieve penetration into the protein interior. This paper discusses some effects and implications of supramolecular Congo red complexation with proteins.

\section{Congo red as a model supramolecular dye}

Interaction of proteins with ligands is usually limited to a binding site at a specific location in the protein molecule. Binding sites are commonly found as cavities in the protein body facilitating contact of the ligand with the hydrophobic interior and separating the ligand from direct dissociation pressure of the surrounding water solution. The specificity and strength of interaction which allows ligand-protein complexation is due to the specific shape of the binding site accommodating the ligand as well as to proper distribution of binding groups.

The strength of non-specific low-contact interaction of organic compounds outside the binding site is generally insufficient to stabilize ligation, even if penetration into the protein interior is occasionally possible. There is, however, an exception to this rule. It concerns self-assembled molecules creating rode-like or ribbon-like supramolecular structures. They are usually formed by elongated, planar aromatic ring-containing organic molecules with (possibly) symmetric distribution of charges in the molecule. Congo red and related dyes are an example (Fig. 1) [27-33]. Theoretical calculations enable modeling of such supramolecular structures, based initially on semi-empirical techniques and then using ab initio parameterization [17, 27]. In contrast to the molecular organization of supramolecular micellar structures with a standard globular shape, where the hydrophobic portions of amphipatic molecules are basically hidden in the micelle, fibrillar structures allow significant exposure, promoting adhesion. This property is further

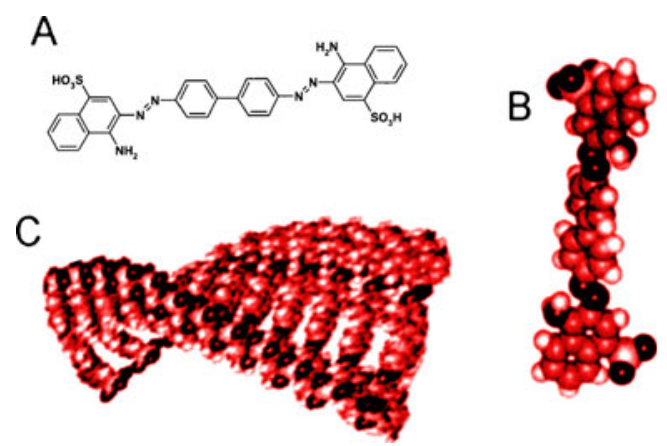

Fig. 1 Congo red-single molecules $(\mathbf{a}, \mathbf{b})$ and supramolecular form of the dye (c) $[17,27]$ enhanced by structural plasticity due to non-covalent stabilization. Pieces of such ribbon-like supramolecular structures consisting of several or more assembled molecules have been confirmed to penetrate into proteins and bind as single ligands. $\beta$-plates in proteins appear to be the most favored acceptor [26, 34-36]. Dye ligands penetrate preferentially in between the polypeptide strands of $\beta$-plates. Replacement of the least stable strand (away from the packing locus) to make room for the dye ligand is a frequently observed phenomenon (Fig. 2) [37, 38]. Well-packed proteins are mostly impervious to dye penetration and - generally speaking - certain structural instabilities seem essential to render the protein capable of binding supramolecular ligands. Instability may occasionally be natural, as in the case of the so-called disordered proteins [39], but more often arises as a result of protein misfolding [40-42], mutation-derived structural alteration [22] or the presence of unfolding conditions [28, 38].

\section{Function-derived secondary structural changes}

In some cases proteins become susceptible to penetration by supramolecular ligands as an effect of structural changes generated in the protein molecule by its function-related activities. This implies that primary structural changes in the protein molecule caused by the ligand itself are often connected with some distant secondary alterations and packing instability which allows Congo red penetration and binding [16, 36, 43-45]. In these cases complexation of supramolecular ligands arrests the primary structural changes connected with the protein's function. The mechanism of this process corresponds to a known type of enzymatic inhibition called uncompetitive inhibition [46]. In the case of enzymes, strong binding of substrates without simultaneous release of products interferes with biological function, causing inhibition. Function-related binding of dye may be studied, e.g., on the basis of known complexes involving acute phase serum proteins. Figure 3 shows the distribution of serum proteins separated by two-dimensional agarose electrophoresis with Congo red added to the second (perpendicular) run (placing the dye below the starting line of proteins) to select and expose proteins interacting with the dye [47]. The rapidly migrating dye accelerates migration of proteins involved in its binding. As a result such proteins outpace the diagonal distribution of proteins which do not engage in binding dye. Selective binding of dye to serum proteins associated with various diseases indicates that proteins exposed by the dye (i.e., those located above the diagonal) may have been altered by pathological processes. This is likely due to complexation of abundant disease-related products. Location of these particular proteins in electrophoretic fractions hints at the nature of the 
Fig. 2 Schematic view of supramolecular Congo red penetration into a locus of decreased stability in a $\beta$-plate. Replacement of one $\beta$-strand by the dye $(\mathbf{a}, \mathbf{b})$

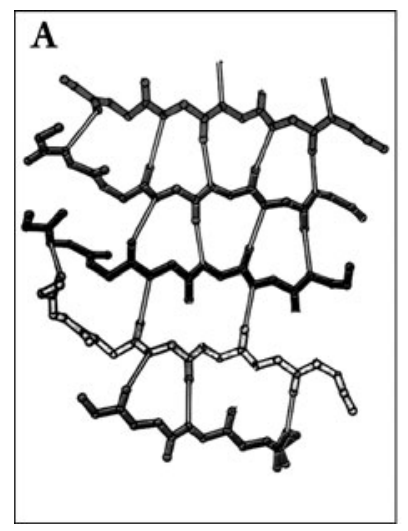

abnormal state in the organism. The phenomenon of function-derived generation of protein susceptibility for Congo red binding is of great interest for theoretical and practical use in biology and medicine.

\section{Immune complexation as the mechanism generating structural alterations allowing Congo red binding}

Antibodies and immune complexation fall squarely within the focus of our interest. Complexation of antibodies with large insoluble antigens (cells, bacteria) generates strains and structural changes in molecules, rendering them susceptible to Congo red binding.

The strains arise as a consequence of fitting and complexation of noncomplementary objects represented here by bivalent antibodies on the one hand, and by randomly distributed antigenic determinants on the other (Fig. 4) [48]. This effect concerns only complete bivalent antibodies and neither Fab nor even $(\mathrm{Fab})_{2}$ complexation is capable of producing it $[43,44]$. Nevertheless, secondary structural alterations in the antibody molecule (caused by antigen ligation) increase its affinity for Congo red and, as a result, promote formation of immune complexes [43, 44, 49-51]. This enhancement effect caused by Congo red binding to immune complexes formed by complete, bivalent antibodies was measured in the SRBC-antiSRBC system using polyclonal antibodies isolated by Sephadex gel filtration and labeled by iodine- 125 . The curve clearly indicates the increased number of antibody molecules bound to red cell following increases in Congo red concentration (Fig. 5). Experiments reveal binding of low-affinity antibodies, naturally present in polyclonal sera, removable without Congo red by washing.

The site of Congo red binding is localized in immunoglobulin $\mathrm{V}$ domains but outside of the antigen binding site $[16,37,38]$. Constraints destabilize the packing of the Nterminal polypeptide chain fragment in the V domain. Destabilization further propagates to elbow regions, enabling rotational movements of polypeptides in the $\mathrm{CH} 1$ domain and, as can be expected, favoring complement fixation. These movements are interpreted as intramolecular signaling $[16,47,52]$. Structural instabilities in V domain favor Congo red penetration. The dye replaces the unstable terminal polypeptide fragment in the packing locus. Theoretical modeling, confirmed by experimental observations, reveals structural changes associated with the binding of supramolecular ligands. [44, 51, 52] A schematic representation of this phenomenon in the $\mathrm{V}$ domain of $\mathrm{L}$ chain is presented in Fig. 6.

\section{The use of Congo red as a target-directed carrier}

The Congo red ligand, composed of several dye molecules derived from a ribbon-like micelle, penetrates into the
Fig. 3 The effect of using twodimensional agarose electrophoresis of serum proteins with Congo red dye fast migrating added to the second; perpendicular electrophoretic run in order to distinguish (by way of faster migration) proteins which become susceptible to binding the dye due to disease-modified function-related structural changes
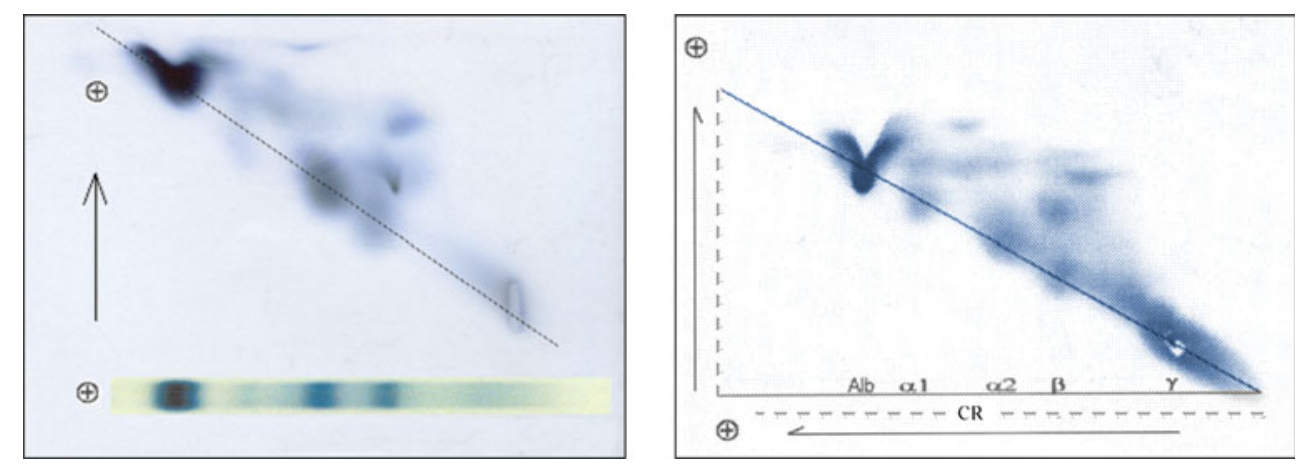


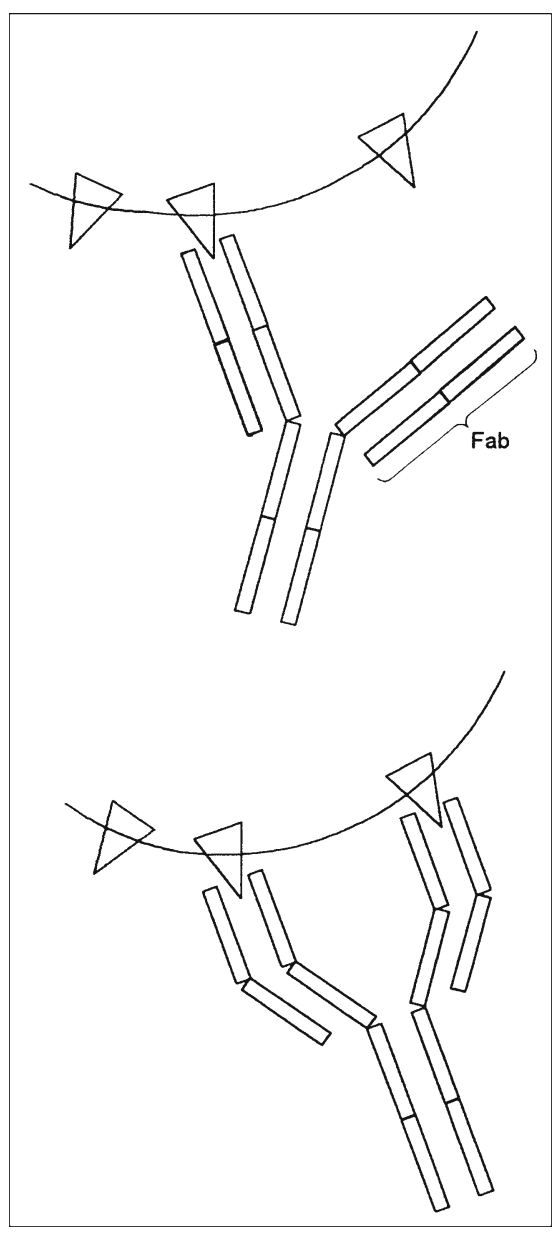

Fig. 4 Schematic presentation of the mechanism explaining generation of constraints in bivalent antibody molecules upon binding to antigen protein body. While its binding strength is rather high, a portion continues to protrude from the protein molecule, creating an external anchor point to which more dye can attach itself. As a result, the protein becomes a carrier for a large quantity of dye. The excess of dye associated with the protein-dye complex may be removed by gel filtration (using bio-gel) or brief reduction by sodium dithionate. Confirmation for these predictions was provided by EM analysis of the isolated by SephadexG200 gel filtration fraction involving $\mathrm{IgG}$ molecules aggregated by heating in the presence of Congo red. The picture shows individual or clustered $\mathrm{IgG}$ molecules as white irregular spots, loaded with an excess of Congo red, preventing the precipitation of partly unfolded (by heating) protein molecules (Fig. 7) $[28,53]$. The non-covalently stabilized supramolecular material attached to the protein may additionally bind foreign compounds, including drugs, by intercalation. In this way foreign compounds with no affinity for the given protein may be introduced to it as "payload" carried by supramolecular dye. Immune complexes which selectively bind Congo red may therefore represent an attractive target model for compounds potentially carried by supramolecular ligands. Congo red with rhodamine $\mathrm{B}$ bound by intercalation was used as the medium for SRBC-antiSRBC agglutinating system to verify the validity of the above mechanism. Agglutinates were studied in UV using a fluorescence microscope [54]. Antibodies were not added to the control sample. Samples were washed carefully to remove the medium containing free dye molecules. Microscope imaging fully confirms that immune complexes act as a receptor system which binds Congo red and therefore becomes the carrier for the included rhodamine B (Fig. 8).
Fig. 5 Increasing the affinity of antibodies to antigen and enhancement of immune complexation upon Congo red binding [45]. The curve shows increasing numbers of (radiolabeled) antiSRBC antibodies (derived from polyclonal serum) bound to the red cell as the concentration of Congo red increases. Congo red binding appears to enable low-affinity antibodies to form immune complexes

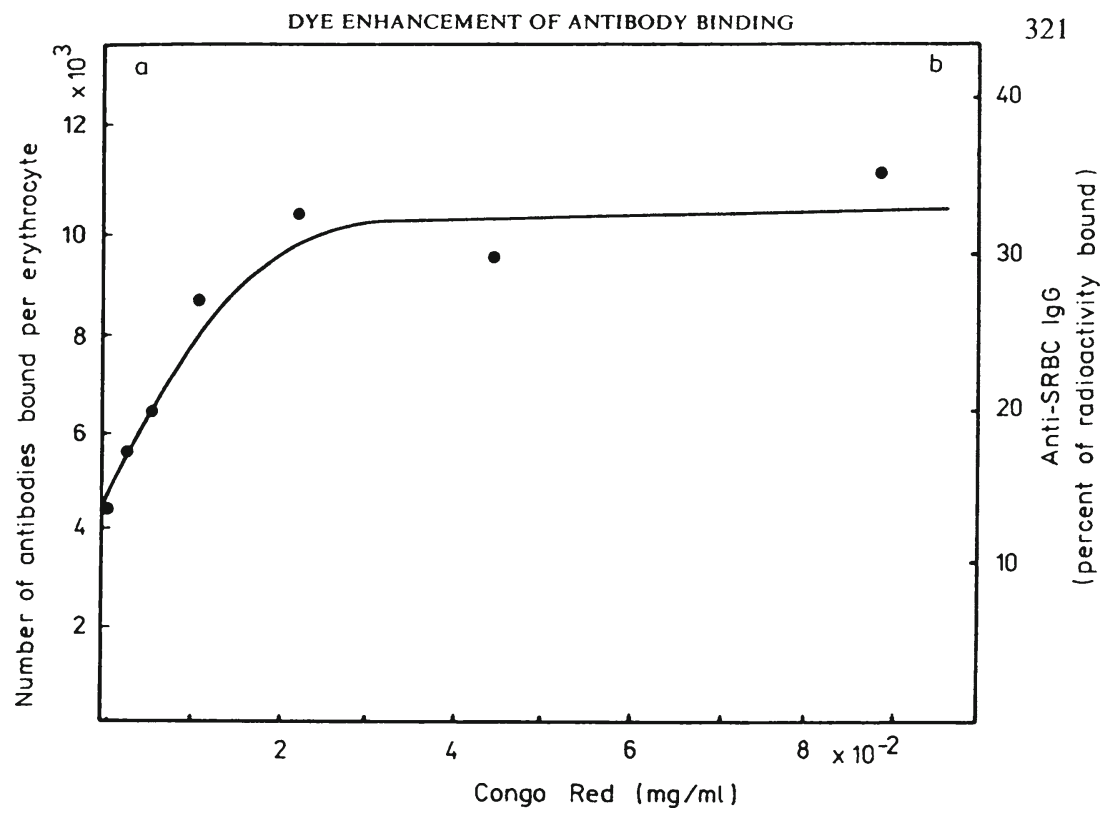


Fig. 6 Schematic view of the IgG $\mathrm{L}$ chain $\mathrm{V}$ domain showing the arrangement of polypeptide strands in $\beta$-sheets $(\mathbf{a}, \mathbf{b})$ and the alterations produced by the complexation of Congo red $(\mathbf{c}, \mathbf{d})$
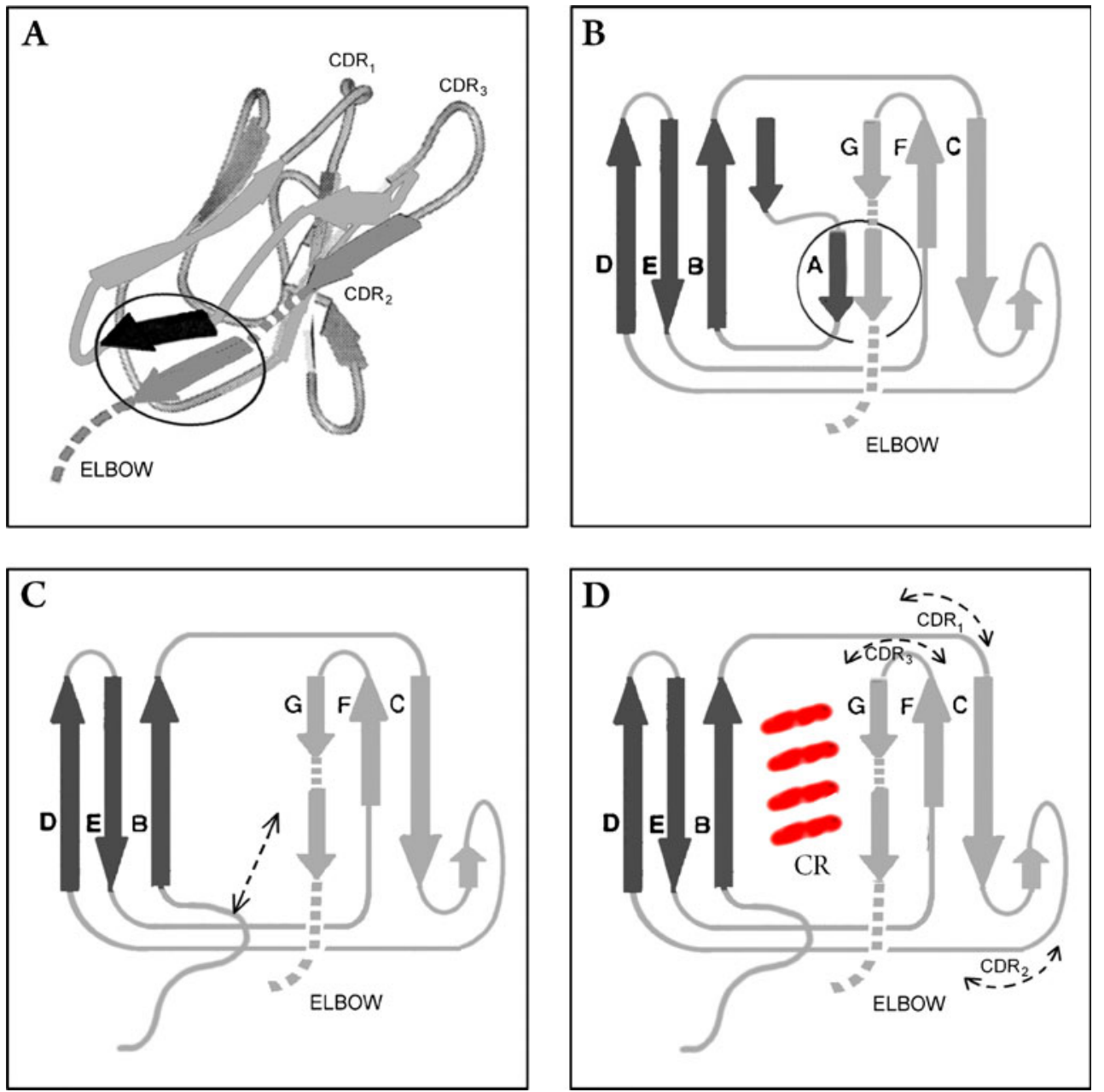

Convincing evidence that immune complexes — but not free antibodies - may become an acceptor for Congo red comes from observations concerning selective binding of dye by immune complexes in vivo. In vivo testing exposes

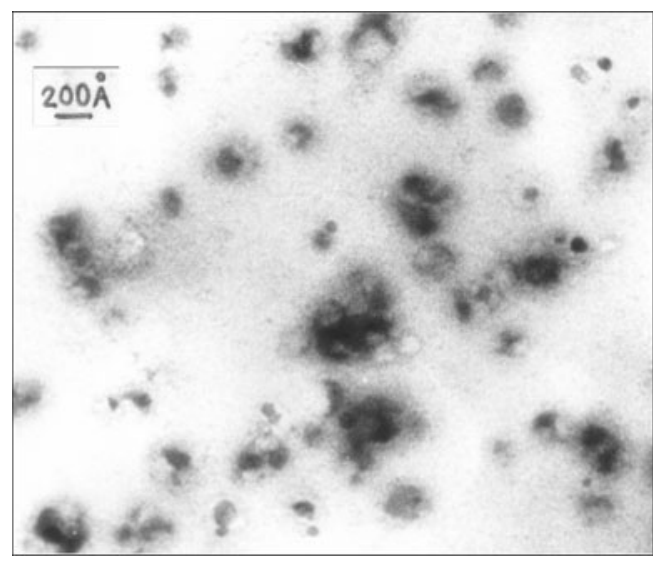

Fig. 7 EM picture of IgG (human) heated with Congo red in conditions standard for aggregation, isolated as high molecular weight fraction by SephatexG200 gel filtration. Single or aggregated molecules of IgG are seen as small irregular white spots within clouds of (silver contrasted) Congo red
Congo red to highly diverse environmental conditions disturbing the carriage thus making the process reliable. As part of these studies, immune complexation was generated
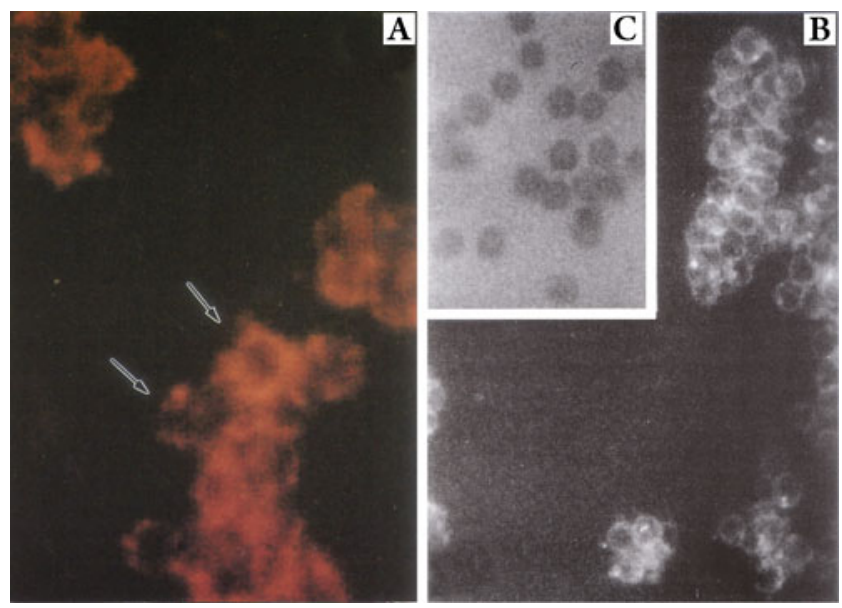

Fig. 8 The use of Congo red as a carrier transporting and introducing rhodamine B (bound by intercalation) to SRBC-antiSRBC immune complexes. Control: red cells treated with dye in the absence of antiSRBC antibodies (a sample in UV, b sample in UV presented in black and white, c control) [54] 
locally in the ear of immunized rabbit by antigen injection (Arthus effect) [55]. This was followed by intravenous injection of Congo red. Owing to the low opacity of rabbit ear tissues, the collection of dye in the locus of injection of
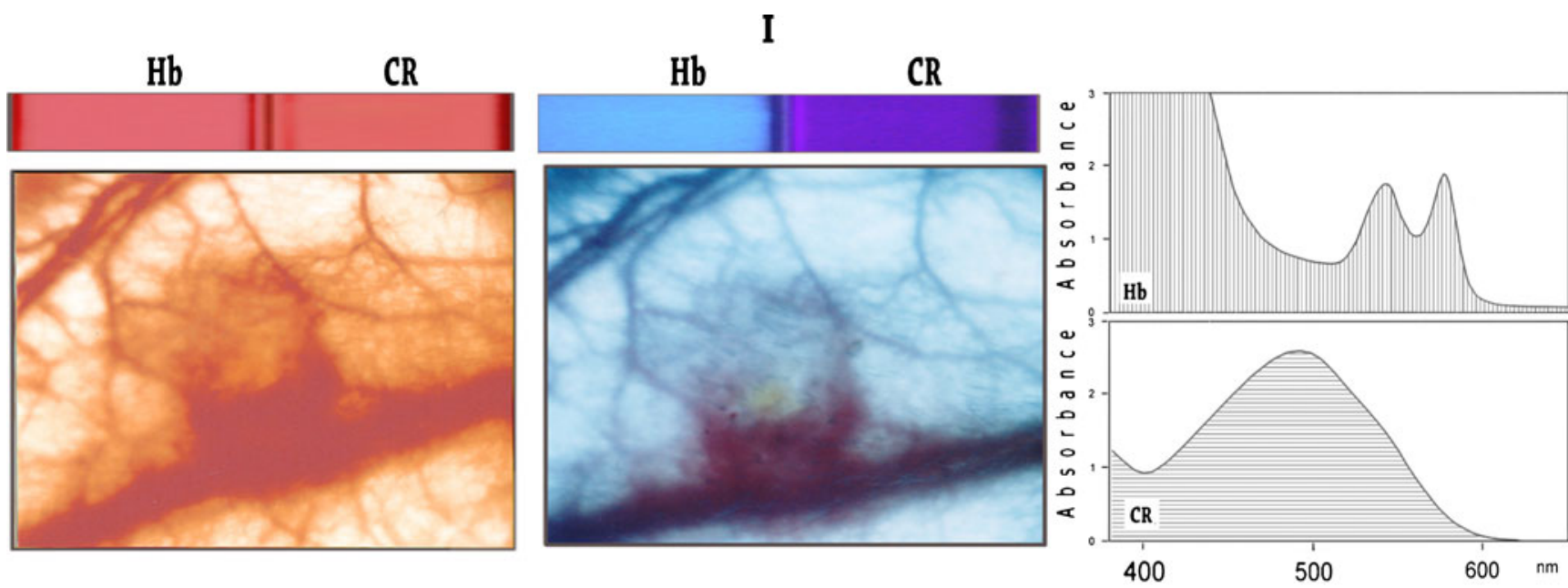

I
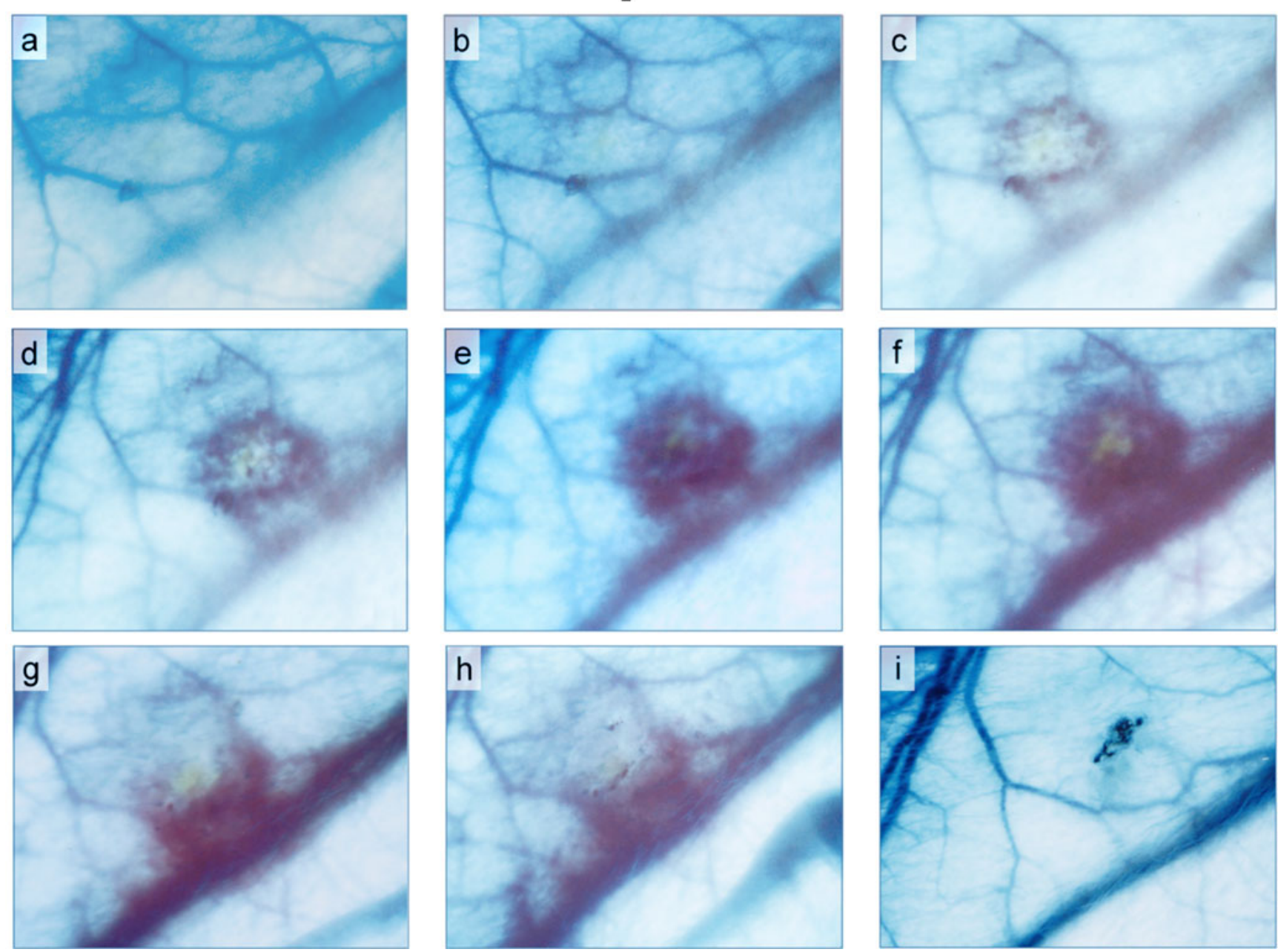

Fig. 9 The kinetics of Congo red binding to immune complexes upon local introduction of an antigen to the ear of immunized rabbit (Arthus effect) followed by intravenous administration of Congo red. A source of visible light was placed in the background and suitable color filters were selected to differentiate hemoglobin and Congo red (top figure). a without filters $\mathbf{b}$ with filters $\mathbf{c} \mathrm{HbO}_{2}$ and Congo red spectra. I - The effect of using filters to differentiate $\mathrm{HBO}_{2}$ and Congo red in solutions and directly in the ear of rabbit - top figure. II - Collection and dispersal of dye - bottom figure 
Fig. 10 Formation of rosettes (mouse monocytes 3774A1 in SRBC-antiSRBC system) via susceptibility of surface proteins to Congo red binding (a UV image; A' visible light image; $\mathbf{b}$ model view)
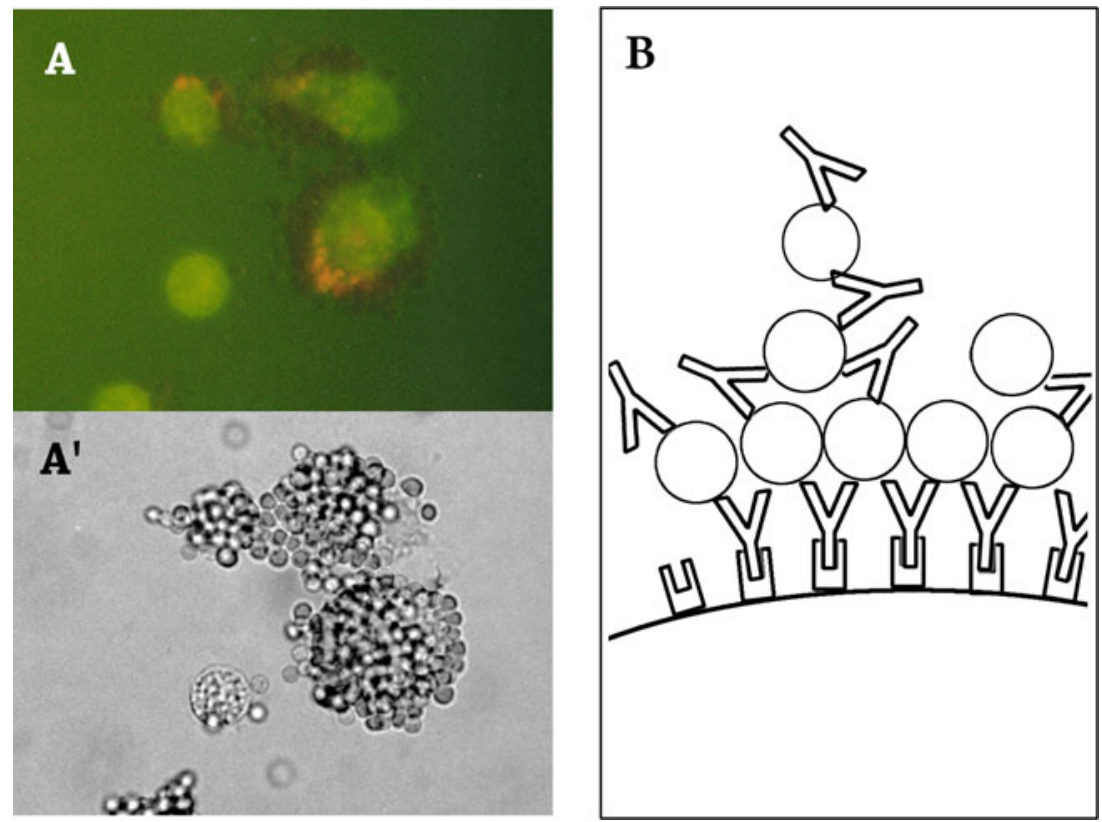

the antigen could be observed using a source of visible light. Pictures were taken using filters which enabled differentiation of $\mathrm{HbO}_{2}$ and Congo red due to their differing spectra. As a result, shades of red (which cannot otherwise be differentiated without the use of filters) appear more blue for $\mathrm{HbO}_{2}$ and more violet for Congo red (Fig. 9I) [56]. The bottom part of Fig. 9II presents the collection and disappearance of Congo red from the vicinity of the antigen over time. The concentration of Congo red in the observed area increases over approximately $20-30 \mathrm{~h}$ and then slowly begins to decrease. The final picture was taken 3 weeks later.
Fig. 11 Binding of Congo red to surface proteins of interacting monocytes and cancer cells (HCV29T human and human monocytes). Fluorescence of Congo red registered in UV and visible light
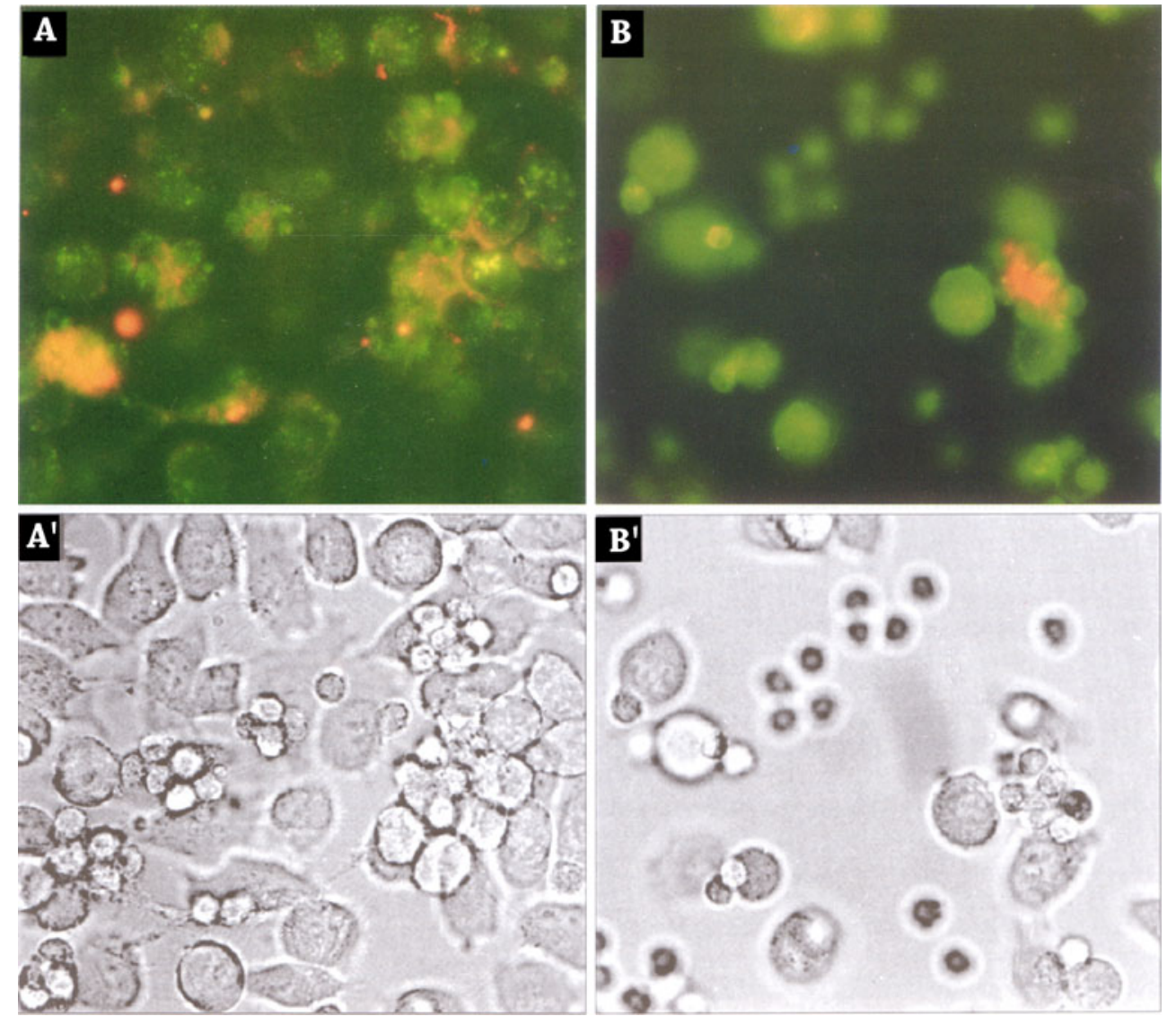


\section{Cell surface proteins interaction with Congo red}

Congo red also attaches to special complexes formed by monocytes or T-lymphocytes and red cells (rosettes) in the presence of specific anti-red-cells antibodies [57-59]. Neither red cells nor monocytes bind the dye themselves. In the present experiment the dye is, however, attached to monocytes forming rosettes. Two kinds of immune complexes are formed in this experimental model. The former is based on antibodies affixed to Fc receptors distributed on the surface of monocytes, while the latter represents antibodies attached to red cells only. This confirms that structural changes in surface proteins engaged in complexation (antibodies $-\mathrm{Fc}$ receptors) are responsible for binding the dye. In the presented case, however, a portion of the attached Congo red was induced to fluorescent emission, which hinted at penetration of dye to more hydrophobic portions of interacting proteins [59]. This phenomenon only involves dye which is engaged in complexation directly on the surface of mouse monocytes (cell line J774A.1, ATTC TIB67) (Fig. 10) [59].

Microscopic pictures taken in UV and visible light reveals the nonhomogeneity of immune complexes formed as rosettes in the SRBC-antiSRBC system on the basis of monocytes as a source of $\mathrm{Fc}$ receptors. Congo red bound to primary antibodies affixed to $\mathrm{Fc}$ receptors appears to emit yellow and red fluorescence, while molecules attached to poorly ordered parts of immune complexes remain inactive. Such behavior seems to be connected with strain within proteins engaged in Congo red binding.

The induced fluorescence of Congo red was also observed to appear when the dye was added to human monocytes interacting with epithelial human bladder transformed cells (HCV29T, Polish Cellular and Molecular Biology Network, UNESCO/PAN) (Fig. 11) [60-64].

The dye binds and produces fluorescence only in conglomerates comprising both kinds of cells, suggesting their mutual interaction, induced strain and subsequent structural alterations of receptor proteins.

\section{Conclusions}

From among many different types of supramolecular structures, rode-like or ribbon-like molecular assemblies reveal an unusual capacity for penetration and binding to protein molecules. The nature of this interaction differs from that of typical ligands as the structures in question bind to areas which are not biologically predisposed to ligation. Moreover, their complexation produces functional enhancement rather than inhibition of the proteins' function. This mechanism can be explained on the basis of numerical analyses of the Congo red molecule structure (the dye chosen as the model), supported by experimental studies $[17,27,28,30$, $31,35,36,44]$.

Having researched the problem for several years we believe we can now present some conclusions regarding this particular type of ligation. It appears to us that the unique properties of supramolecular assemblies of ribbon-like micellar structures forming nonstandard complexes with proteins and penetrating into their interior outside of the binding site are the result of:

1. Relatively large area of interaction (contact surface), ensuring sufficient binding strength for complexation;

2. Exposure of hydrophobicity along the ligand, favoring adhesion to polypeptide chains;

3. Plasticity of the supramolecular ligand which results from non-covalent stabilization and facilitating structural fitting.

To satisfy the binding conditions, the supramolecular ligand must exhibit:

A - Sufficiently strong self-assembling tendencies to preserve the integrity of the ligand during complexation with the protein molecule;

B - Sufficient spacing of charges in the ligand molecule, which is necessary to avoid conflicting interactions upon penetration into the protein interior.

The binding requirements related to the protein structure can be summarized as follows:

1. A necessary prerequisite for binding supramolecular ligands is a local structural instability, which may be caused by the presence of unfolding conditions or by structural alteration associated with the protein's function.

2. $\beta$-structures seem preferable as a binding target in proteins.

Understanding of the supramolecular ligand binding mechanism creates interesting application opportunities in biological studies and medicine.

Open Access This article is distributed under the terms of the Creative Commons Attribution License which permits any use, distribution, and reproduction in any medium, provided the original author(s) and the source are credited.

\section{References}

1. Kar S, Roy K (2012) QSAR of phytochemicals for the design of better drugs. Expert Opin Drug Discov 7(10):877-902

2. Shurtleff AC, Nguyen TL, Kingery DA, Bavari S (2012) Therapeutics for filovirus infection: traditional approaches and progress towards in silico drug design. Expert Opin Drug Discov $7(10): 935-954$

3. Amabilino DB (2009) How deformation can lend a hand to molecular ordering. Science 325:402-403

4. Bhosale S, Sisson AL, Talukdar P, Fürstenberg A, Banerji N, Vauthey E, Bollot G, Mareda J, Röger C, Würthner F, Sakai N, 
Matile S (2006) Photoproduction of proton gradients with $\pi$ stacked fluorophore scaffolds in lipid bilayers. Science 313:84-86

5. Hu C, Chen Z, Shen A, Shen X, Li J, Hu S (2006) Water-soluble single-walled carbon nanotubes via noncovalent functionalization by a rigid, planar and conjugated diazo dye. Carbon 44:428-434

6. Hunter CA, Lawson KR, Perkins J, Urch CJ (2001) Aromatic interactions. J Chem Soc Perkin Trans 2:651-669

7. Jonkheijm P, van der Schoot P, Schenning APHJ, Meijer EW (2006) Probing the solvent-assisted nucleation pathway in chemical self-assembly. Science 313:80-83

8. Kozmik V, Kovarova A, Kuchar M, Svoboda J, Novotna V, Glogarova M, Kroupa J (2006) Novel polymerizable bent-shaped monomeric molecules. Liq Cryst 33:41-56

9. Lai L-L, Su F-Y, Lin Y-J, Ho C-H, Wang E, Hung C-H, Liu Y-H, Wang Y (2002) Synthesis and study of azo-dye compounds: various molecular stackings from different polarities of the molecule. Helv Chim Acta 85:1517-1522

10. Pergamenshchik VM, Gayvoronsky VY, Yakunin SV, Vasyuta RM, Nazarencko VG (2006) Hypothesis of dye aggregation in a nematic liquid crystal: from experiment to a model of the enhanced Lightdirector interaction. Mol Cryst Liq Cryst 454:145/547-156/558

11. Rogers JA, Lagally MG, Nuzzo RG (2011) Synthesis, assembly and applications of semiconductor nanomembranes. Nature 477:45-53

12. Stupp SI, LeBonheur V, Walker K, Li LS, Huggins KE, Keser M, Amstutz A (1997) Supramolecular materials: self-organized nanostructures. Science 276:384-389

13. Travesset A (2011) Self-assembly enters the design era. Science 334:183-184

14. Frid P, Anisimov SV, Popovic N (2007) Congo red and protein aggregation in neurodegenerative diseases. Brain Res Rev 53:136-160

15. Palmer LC, Velichko YS, de la Cruz MO, Stupp SI (2007) Supramolecular self-assembly codes for functional structures. Phil Trans R Soc A 365:1417-1433

16. Piekarska B, Rybarska J, Stopa B, Zemanek G, Król M, Roterman I, Konieczny L (1999) Supramolecularity creates nonstandard protein ligands. Acta Biochim Pol 46:841-851

17. Skowronek M, Stopa B, Konieczny L, Rybarska J, Piekarska B, Szneler E, Bakalarski G, Roterman I (1998) Self-assembly of Congo red-A theoretical and experimental approach to identify its supramolecular organization in water and salt solutions. Biopolymers 46:267-281

18. Khurana R, Uversky VN, Nielsen L, Fink AL (2001) Is Congo red an amyloid-specific dye ? J Biol Chem 276:22715-22721

19. Kim Y-S, Randolph TW, Manning MC, Stevens FJ, Carpenter JF (2003) Congo red populates partially unfolded states of an amyloidogenic protein to enhance aggregation and amyloid fibril formation. J Biol Chem 278:10842-10850

20. Spólnik P, Konieczny L, Piekarska B, Rybarska J, Stopa B, Zemanek G, Król M, Roterman I (2004) Instability of monoclonal myeloma protein may be identified as susceptibility to penetration and binding by newly synthesized Congo red derivatives. Biochimie 86:397-401

21. Spólnik P, Konieczny L, Piekarska B, Rybarska J, Stopa B, Zemanek G, Drozd A, Król M, Roterman I, Wolska-Smoleń T, Skotnicki AB (2005) Congo red - derived supramolecular dyes as probes for disclosure of the aggregation tendency of abnormal monoclonal immunoglobulins. Pol J Environ Stud 14:776-781

22. Spólnik P, Piekarska B, Stopa B, Konieczny L, Zemanek G, Rybarska J, Król M, Nowak M, Roterman I (2003) The structural abnormality of myeloma immunoglobulins tested by Congo red binding. Med Sci Monit 9:145-153

23. Wu C, Wang Z, Lei H, Zhang W, Duan Y (2007) Dual binding modes of Congo red to amyloid protofibril surface observed in molecular dynamics simulations. J Am Chem Soc 129: $1225-1232$
24. Rybarska J, Piekarska B, Stopa B, Zemanek G, Konieczny L, Nowak M, Król M, Roterman I, Szymczakiewicz-Multanowska A (2001) Evidence that supramolecular Congo red is the sole ligation form of this dye for $\mathrm{L}$ chain $\lambda$ derived amyloid proteins. Folia Histochem Cytobiol 39:307-314

25. Stopa B, Konieczny L, Piekarska B, Roterman I, Rybarska J, Skowronek M (1997) Effect of self-association of bis-ANS and bis-azo dyes on protein binding. Biochimie 79:23-26

26. Stopa B, Górny M, Konieczny L, Piekarska B, Rybarska J, Skowronek M, Roterman I (1998) Supramolecular ligands: Monomer structure and protein ligation capability. Biochimie 80:963-968

27. Król M, Borowski T, Roterman I, Piekarska B, Stopa B, Rybarska J, Konieczny L (2004) Force-field parameterization and molecular dynamics simulation of Congo red. J Comput Aided Mol Des $18: 41-53$

28. Roterman I, No KT, Piekarska B, Kaszuba J, Pawlicki R, Rybarska J, Konieczny L (1993) Bis azo dyes - Studies on the mechanism of complex formation with $\operatorname{IgG}$ modulated by heating or antigen binding. J Physiol Pharmacol 3:213-232

29. Rudyk H, Knaggs MH, Vasiljevic S, Hope J, Birkett C, Gilbert IH (2003) Synthesis and evaluation of analogues of Congo red as potential compounds against transmissible spongiform encephalopathies. Eur J Med Chem 38:567-579

30. Skowronek M, Roterman I, Konieczny L, Stopa B, Rybarska J, Piekarska B, Górecki A, Król M (2000) The structure of Congo Red, Evans Blue and Trypan Blue as seen in calculation using different methods. Comput Chem 24:429-450

31. Skowronek M, Roterman I, Konieczny L, Stopa B, Rybarska J, Piekarska B (2000) Why do Congo Red, Evans Blue and Trypan Blue differ in their complexation properties? J Comput Chem 21:656-667

32. Stopa B, Piekarska B, Konieczny L, Rybarska J, Spólnik P, Zemanek G, Król M, Roterman I (2003) The structure and protein binding of amyloid-specific dye reagents. Acta Biochim Pol 50:1213-1227

33. Stopa B, Piekarska B, Konieczny L, Król M, Rybarska J, Jagusiak A, Spólnik P, Roterman I, Urbanowicz B, Piwowar P, Lewiński K (2010) Formation of amyloid-like aggregates through the attachment of protein molecules to a Congo red scaffolding framework ordered under the influence of an electric field. CEJOR 8(1):41-50

34. Piekarska B, Skowronek M, Rybarska J, Stopa B, Roterman I, Konieczny L (1996) Congo Red - stabilized intermediates in the $\lambda$ light chain transition from native to molten state. Biochimie 78:183-189

35. Roterman I, Rybarska J, Konieczny L, Skowronek M, Stopa B, Piekarska B (1998) Congo Red bound to $\alpha$-1-proteinase inhibitor as a model of supra-molecular ligand and protein complex. Comput Chem 22:61-70

36. Roterman I, Król M, Nowak M, Konieczny L, Rybarska J, Stopa B, Piekarska B, Zemanek G (2001) Why Congo red binding is specific for amyloid proteins. Med Sci Monit 7(4):771-784

37. Król M, Roterman I, Piekarska B, Konieczny L, Rybarska J, Stopa B (2003) Local and long-range structural effects caused by the removal of the N-terminal polypeptide fragment from immunoglobulin L chain. Biopolymers 69:189-200

38. Piekarska B, Konieczny L, Rybarska J, Stopa B, Zemanek G, Szneler E, Król M, Nowak M, Roterman I (2001) The heat induced formation of a specific binding site for self-assembled Congo red in $\mathrm{V}$ domain of immunoglobulin chain $\lambda$. Biopolymers 59: 446-456

39. Sugase K, Dyson HJ, Wright PE (2007) Mechanism of coupled folding and binding of an intrinsically disordered protein. Nature 447:1021-1025

40. Cohen FE (1999) Protein misfolding and prion diseases. J Mol Biol 293:313-320 
41. Krishna MMG, Lin Y, Englander SW (2004) Protein misfolding: optional barriers, misfolded intermediates and pathway heterogeneity. J Mol Biol 343:1095-1109

42. Reynaud E (2010) Protein misfolding and degenerative diseases. Nat Educ 3(9):28-34

43. Kaszuba J, Konieczny L, Piekarska B, Roterman I, Rybarska J (1993) Bis-azo dyes interference with effector activation of antibodies. J Physiol Pharmacol 44:233-242

44. Król M, Roterman I, Drozd A, Konieczny L, Piekarska B, Rybarska J, Spólnik P, Stopa B (2006) The increased flexibility of CDR loops generated in antibodies by Congo red complexation favors antigen binding. J Biomol Struct Dyn 23:407-415

45. Rybarska J, Konieczny L, Roterman I, Piekarska B (1991) The effect of azo dyes on the formation of immune complexes. Arch Immunol Ther Exp 39:317-327

46. Devlin TM (2011) Textbook of Biochemistry with clinical correlations. Wiley, New York, p 408

47. Rybarska J, Konieczny L, Piekarska B, Stopa B, Roterman I (1995) The detection of specific acute phase serum protein complexes and immune complexes by Congo red binding to serum proteins components. J Physiol Pharmacol 46:221-231

48. Piekarska B, Stopa B, Konieczny L, Rybarska J, Zemanek G, Spólnik P, Roterman I, Król M (2004) Intramolecular signaling in immunoglobulins - new evidence emerging from the use of supramolecular protein ligands. J Physiol Pharmacol 55:487-501

49. Drozd A, Konieczny L, Piekarska B, Rybarska J, Stopa B, Zemanek G (2006) How specially adapted chromatographic bed material might be used for the controlled formation of immune complexes and studies of Congo red binding to bivalent antibodies. Bio-Algorithm Med-Syst 2(4):25-28

50. Uracz W, Bobrzecka K, Konieczny L, Rybarska J, Zembala M (1984) The use of Fab-Fc recombinant antibodies for studying the mechanism of triggering the effector activities of immunoglobulins. Immunol Lett 7:215-220

51. Piekarska B, Drozd A, Konieczny L, Król K, Jurkowski W, Roterman I, Spólnik P, Stopa B, Rybarska J (2006) The indirect generation of long-distance structural changes in antibodies upon their binding to antigen. Chem Biol Drug Des 68:276-283

52. Król M, Roterman I, Piekarska B, Konieczny L, Rybarska J, Stopa B, Spólnik P, Szneler E (2005) An approach to understand the complexation of supramolecular dye Congo red with immunoglobulin L chain lambda. Biopolymers 77:155-162

53. Piekarska B, Konieczny L, Rybarska J (1988) The effect of azo dyes on heat aggregation of IgG. Acta Biochim Pol 35:297-305
54. Konieczny L, Piekarska B, Rybarska J, Skowronek M, Stopa B, Dabros W, Pawlicki R, Roterman I (1997) The use of Congo Red as a lyotropic liquid crystal to carry stains in a model immunotargeting system-microscopic studies. Folia Histochem Cytobiol $35: 203-210$

55. Weir DM (1973) Immunochemistry vol 1. Blackwell Scientific, Publications-Oxford, London

56. Rybarska J, Piekarska B, Stopa B, Spólnik P, Zemanek G, Konieczny L, Roterman I (2004) In vivo accumulation of selfassembling dye Congo red in an area marked by specific immune complexes: possible relevance to chemotherapy. Folia Histochem Cytobiol 42:101-110

57. Roitt IM, Brostoff J, Male DK (1993) Immunology 3rd edn. Gower, London

58. Zemanek G, Rybarska J, Stopa B, Piekarska B, Spolnik P, Konieczny L, Roterman I, Bugajski A (2003) Protein distortionderived mechanism of signal discrimination In monocytes revealed using Congo red to stain activated cells. Folia Histochem Cytobiol 41(3):113-124

59. Zemanek G, Jagusiak A, Kusior D, Piekarska B, Spólnik P, Stopa B (2011) Application of numerical analysis of fluorescence spectrum to identify properties of substances associating with Congo red micelle. Bio-Algorithm Med-Syst 7:17-23

60. Gerrard TL, Terz JJ, Kaplan AM (1980) Cytotoxity to tumor cells of monocytes from normal individuals and cancer patients. Int $\mathrm{J}$ Cancer 26:585-593

61. Golightly MG, Fischer DG, Öhlander C, Koren HS (1983) Characteristics and requirements of the interaction between human monocytes and tumour cells on the single cell level. Blood 61:390-396

62. Muse KE, Koren HS (1982) Interactions between fresh human blood monocytes and tumour targets at the single cell level: binding and morphological characteristics. J Reticuloendothel Soc 32:323-337

63. Shimizu H, Wyatt D, Knowles RD, Bucana CD, Stanbridge EJ, Kleinerman ES (1989) Human monocytes selectively bind to cells expressing the tumorigenic phenotype. Cancer Immunol Immunother 28:185-192

64. Siedlar M, Mytar B, Hyszko M, Zembala M (1999) Involvement of protein kinases in signalling for nitric oxide (NO) and tumour necrosis factor alpha (TNF) production by monocytes stimulated with colorectal DeTa cancer cells: the lack of evidence for the role of TNF in the regulation of NO production. Immunol Lett 65:189-195 